\title{
ANALISIS PENGGUNAAN ABU TANDAN KELAPA SAWIT SEBAGAI FILLER DITINJAU DARI NILAI KEAUSAN PERKERASAN (CANTABRO TEST)
}

\author{
Winayati, Hendri Rahmat, Alfian Saleh \\ Dosen Jurusan Teknik Sipil Fakultas Teknik Universitas Lancang Kuning \\ Jl.Yos Sudarso Km. 8 Rumbai-Pekanbaru \\ Email:winayatimt@gmail.com,mutilab_one@yahoo.comdanalfian.saleh@gmail.com
}

\begin{abstract}
ABSTRAK
Material yang umum digunakan sebagai filler campuran perkerasan lentur adalah semen, dan abu batu, yang persediaannya terbatas dan harganya relatif mahal, bila dilihat dari sumber materialnya bahan perkerasan ini tidak dapat diperbaharui. Penggunaan abu tandan sawit sebagai filler merupakan bahan alternatif lain yang didapat dari limbah industri pengolahan kelapa sawit, bahan ini merupakan sumber daya alam yang dapat diperbaharui. Penelitian ini bertujuan untuk menganalisis keausan campuran AC-BC (Asphalt Concrete - Binder Course) menggunakan bahan pengisi (Filler) abu tandan kelapa sawit, dengan persentase $25 \%$ abu tandan sawit - 75\% abu batu, dengan Spesifikasi Umum Bina Marga 2010 di laboratorium. Aspal beton direncanakan untuk lalu lintas berat, campuran dengan kadar aspal optimum, prosentase $25 \%$ abu tandan sawit $-75 \%$ abu batu. Pengujian keausan benda uji ini direncanakan menggunakan pengujian Cantabro Test. Dari hasil Cantabro Test menunjukkan bahwa campuran AC-BC yang menggunakan abu tandan sawit pada komposisi filler $75 \%$ debu batu $+25 \%$ abu tandan sawit merupakan komposisi yang optimum dalam menggunakan zeolit alam sebagi filler. Berdasarkan hasil uji Cantabro Test yang didapatkan bahwasanya tingkat aus sebesar 8,24\% dan memenuhi standar spesifikasi Bina Marga 2010 yaitu nilai keausan $\leq 20 \%$. Sehingga penggunaan abu tandan sawit sebagai filler dengan komposisi $75 \%$ debu batu+25\% abu tandan sawit ini terhadap perkerasan aspal dapat memberikan kontribusi dalam ketahanan perkerasan aspal terhadap gesekan roda kendaraan dengan permukaan jalan. Perlu dilakukan penelitian lebih lanjut mengenai pengaruh variasi filler pencampuran dan penumbukan terhadap filler lain.
\end{abstract}

Kata Kunci : Abu Tandan Sawit, AC-BC, Cantabro Tets, Filler 


\begin{abstract}
Materials commonly used as a filler mix of flexible pavements are cement and stone dust, which is in limited supply and relatively expensive when viewed from the source material pavement materials can not be renewed. The use of palm bunch ash as filler is another alternative material obtained from waste palm oil processing industry, this material is a natural resource that can be renewed. This study aimed to analyse the wear mix AC-BC (Asphalt Concrete - Binder Course) using a filler (Filler) ash palm bunches, with a percentage of $25 \%$ ash bunches of oil - $75 \%$ grey stone, with the General Specifications DGH 2010 in the laboratory. Asphalt concrete is planned to heavy traffic, the mixture with the optimum bitumen content, the percentage of $25 \%$ ash bunches of oil - $75 \%$ of stone dust. Testing is planned to wear specimen using Test Cantabro testing. From Cantabro Test results show that a mixture of $A C-B C$ that use palm bunch ash in the composition of rock dust filler $75 \%+25 \%$ ash bunches of a palm is optimal compositions in using natural zeolite as a filler. Based on test results obtained Cantabro Test that keausannya rate of $8.24 \%$ and meet the standard specifications of Highways in 2010 a value of wear $\leq 20 \%$. So the use of palm bunch ash as filler in the composition of rock dust $75 \%+25 \%$ ash palm bunches against the asphalt pavement can contribute to the resistance of asphalt pavement to the friction wheels of the vehicle with the road surface. Need to do more research regarding the effect of variation filler blending and pulverization of the other filler.
\end{abstract}

Keywords: Ash Bunches Oil, AC-BC, Cantabro Test, Filler

\title{
1. Pendahuluan
}

Lapis aspal beton adalah perkerasan jalan yang terdiri dari campuran agregat dan aspal, dengan atau tanpa bahan tambah.Materialmaterial pembentuk aspal beton dicampur pada suhu tertentu, kemudian diangkut ke lokasi, dihampar lalu dipadatkan.Suhu pencampuran antara $145-155^{\circ} \mathrm{C}$, disebut aspal beton campuran panas.Campuran ini dikenal dengan hotmix (Sukirman, 2003). Abu tandan sawit merupakan salah satu limbah yang dihasilkan oleh industri perkebunan kelapa sawit memberikan peluang alternatif sebagai material penyusun campuran aspal. Sebagai gambaran umum bahwa pabrik yang mengolah kelapa sawit dengan kapasitas 200 ton TBS/hari akan menghasilkan
Abu tandan sawit sebesar 10,8\%/hari (Fauzi dkk, 2002).Pemanfaatan tandan kelapa sawit masih relatif terbatas, yaitu digunakan langsung sebagai mulsa di perkebunan kelapa sawit, atau dibakar dalam incinerator dan abunya dimanfaatkan sebagai substitusi pupuk kalium.

Berdasarkan pengujian awal terhadap Abu Tandan Sawit, dari analisis saringan diperoleh hasil bahwa Abu Tandan Sawit 65\% lolos saringan No.200, pada pengujian saringan basah filler Abu Tandan Sawit memenuhi gradasai yang ditentukan dan pengujian penentuan indeks plastisitas menunjukkan Bahwa Abu Tandan Sawit 
ialah bahan non plastis, sesuai dengan persyaratan untuk bahan pengisi.

Hasil penelitian Aulia Afrian 2016 direkomendasikan campuran $A C-B C$ yang memenuhi Spesifikasi Umum Bina Marga 2010, 25\% filler abu tandan sawit dicampur dengan $75 \%$ Abu Batu dari berat total filler dalam campuran.Variasi tersebut dalam campuran $A C-B C$ memenuhi standar karakteristik Marshall, yaitu stabilitas, flow, VIM, VMA, VFA, MQ, IRS. Dari rekomendasi penelitian ini, dilakukan penelitian lanjutan sesuai dengan tema yaitu meninjau nilai keausan perkerasan dengan komposisi tersebut dengan pengujian Cantabro Test.

\section{Kajian Literatur}

Perkerasan jalan adalah campuran agregat dan bahan ikat yang diletakkan di atas tanah dasar dengan pemadatan untuk melayani beban lalu lintas. Tujuan utama pembuatan struktur perkerasan jalan adalah untuk mengurangi tegangan atau tekanan akibat beban roda sehingga mencapai tingkat nilai yang dapat diterima oleh tanah yang menyokong beban tersebut (Ahmad, 2010).

Lapis aspal beton atau $A C$ (Asphalt Concrete) merupakan salah satu campuran beraspal dimana kekuatan campurannya ditentukan oleh daya ikat (interlocking) antar agregat, bahan pengisi (filler) dan bahan pengikat (asphalt).Daya ikat antar agregat merupakan penyokong utama bagi kekuatan dan performa material pada struktur perkerasan.Oleh karena itu, permukaan jalan dapat menahan beban dengan baik ketika kendaraan melewatinya (Ahmad, 2010).

AC-BC (Asphalt Concrete-Binder Course) adalah salah satu dari tiga macam campuran AC, yaitu AC-BC (Asphalt Concrete-Binder Course), ACWC (Asphalt Concrete-Wearing Course), AC-Base.Perbedaan ketiga campuran terletak pada perbedaan ukuran bahan agregat yang digunakan sesuai dengan Spesifikasi Umum Bina Marga 2010 (Bina Marga, 2010).

Pembuatan Aspal Beton untuk mendapatkan suatu lapis permukaan atau lapis antara pada perkerasan jalan raya, campuran $A C$ terdiri dari material-material yang dihamparkan dan dipadatkan dalam keadaan panas pada suhu tertentu. Adapun bahan penyusun aspal beton:

\section{a) Agregat}

Agregat adalah sekumpulan butiran batuan yang berukuran tertentu yang diperoleh dari hasil alam langsung maupun dari pemecahan batu besar ataupun agregat yang disengaja dibuat untuk tujuan tertentu. Agregat dapat berupa berbagai jenis butiran atau pecahan batuan, termasuk di dalamnya antara lain : pasir, kerikil, agregat pecah, abu/debu agregat dan lain-lain (Putrowijoyo 2006).

\section{b) Bahan Pengisi (Filler)}

Bahan pengisi adalah bahan yang lolos ukuran saringan No.30 (0,59 mm) dan paling sedikit $65 \%$ lolos saringan No.200 (0,075 mm) berdasarkan SNI 
03-6723 (Standar Nasional Indonesia Spesifikasi Bahan Pengisi untuk Campuran Beraspal, 2002). Fungsi dari bahan pengisi adalah sebagai pengisi rongga-rongga antar agregat yang diharapkan dapat meningkatkan kerapatan dan memperkecil permeabilitas dari campuran, keuntungan lain dengan adanya bahan pengisi adalah karena banyak menyerap aspal maka akan menaikkan volumenya.

Biasanya untuk bahan pengisi menggunakan abu batu. Namun dalam perkembangannya banyak yang menggunakan bahan pengisi lain dengan persentase tertentu dengan menggabungkan bahan lain seperti abu tandan sawit

\section{c) Abu Tandan Sawit (ATS)}

Tandan sawit sebagai sisa pengolahan pabrik kelapa sawit dalam bentuk padat dibakar dan akan menghasilkan Abu Tandan Sawit. Adapun komposisi kandungan kimia Abu Tandan Sawit ditunjukkan Tabel 1 berikut ini:

Tabel 1. Komposisi Kandungan Kimia Abu Tandan Sawit

\begin{tabular}{|l|c|}
\hline Parameter & Hasil analisis $(\%)$ \\
\hline Kalium $(\mathrm{K})$ & 25,8 \\
\hline Silika $(\mathrm{Si})$ & 19,1 \\
\hline Calsium $(\mathrm{Ca})$ & 2,7 \\
\hline Magnesium $(\mathrm{Mg})$ & 2,8 \\
\hline Natrium $(\mathrm{Na})$ & 0.03 \\
\hline Posfat & 0,2 \\
\hline Klor $(\mathrm{Cl})$ & 4,9 \\
\hline C03 & 9,2 \\
\hline
\end{tabular}

(sumber: Zahrina, 2007) d) Aspal

Aspal dibuat dari minyak mentah (crude oil) dan secara umum berasal dari sisa organisme laut dan sisa tumbuhan laut dari masa lampau yang tertimbun oleh dan pecahan batu batuan.Setelah berjuta juta tahun material organis dan lumpur terakumulasi dalam lapisan lapisan setelah ratusan meter, beban dari beban teratas menekan lapisan yang terbawah menjadi batuan sedimen.Sedimen tersebut yang lama kelamaan menjadi atau terproses menjadi minyak mentah senyawa dasar hydrocarbon.Aspal biasanya berasal dari destilasi minyak mentah tersebut (Putrowijoyo, 2006).

\section{Karakteristik Beton Aspal}

Suatu perkerasan harus memiliki karakteristik tertentu sehingga kuat menahan beban serta aman dan nyaman ketika dilalui kendaraan, (Putrowijoyo, 2006) seperti :

a) Stabilitas (Stability)

The Asphalt Institute menyatakan bahwa stabilitas adalah kemampuan campuran aspal untuk menahan deformasi akibat beban yang bekerja, tanpa mengalami deformasi permanen seperti gelombang, alur ataupun bleeding dinyatakan dalam satuan $\mathrm{kg}$ atau lb. Nilai stabilitas diperoleh dari hasil pembacaan langsung pada alat Marshall Test sewaktu melakukan pengujian Marshall. Stabilitas terjadi dari hasil geseran antar butir, penguncian antar partikel dan daya ikat yang baik dari lapisan aspal.Dengan demikian stabilitas yang tinggi dapat 
diperoleh dengan penggunaan agregat dengan gradasi yang rapat, agregat dengan permukaan kasar dan aspal dalam jumlah yang cukup.

b) Kelelahan (flow)

Flow adalah besarnya deformasi vertikal benda uji yang terjadi mulai saat awal pembebanan sampai kondisi kestabilan maksimum sehingga sampel sampai batas runtuh dinyatakan dalam satuan mm. Nilai flow yang tinggi mengindikasikan campuran bersifat plastis dan lebih mampu mengikuti deformasi akibat beban, sedangkan nilai flow yang rendah mengindikasikan campuan tersebut memiliki banyak rongga yang tidak terisi aspal sehingga campuran berpotensi untuk mudah retak. Pengukuran flow bersamaan dengan pengukuran nilai stabilitas Marshall. Nilai flow juga diperoleh dari hasil pembacaan langsung pada alat Marshall Test sewaktu melakukan pengujian Marshall.

c) Durabilitas

Durabilitas yaitu kemampuan suatu lapis perkerasan jalan untuk mempertahankan diri dari kerusakan atau mencegah keausan karena pengaruh lalu lintas, pengaruh cuaca dan perubahan suhu yang terjadi selama umur rencana.

d) Tahanan geser (Skid Resistance)

Skid resistance menunjukkan kekesatan permukaan perkerasan untuk mengurangi selip pada kendaraan saat perkerasan dalam keadaan basah atau kering. Hal ini terjadi karena pada saat terjadi hujan kekesatan pada lapis permukaan akan berkurang walaupun tidak sampai terjadi aquaplaning. Kekesatan dinyatakan dengan koefisien gesek antara permukaan jalan dan ban kendaraan.

e) Fleksibilitas

Fleksibilitas pada lapisan perkerasan adalah kemampuan lapisan untuk mengikuti deformasi yang terjadi akibat beban lalu lintas berulang tanpa timbulnya retak dan perubahan volume.

f) Porositas

Porositas adalah kandungan udara yang terdapat pada campuran perkerasan.Porositas berfungsi untuk mengalirkan air permukaan secara sempurna bersamaan dengan kemiringan perkerasan sehingga dapat mengurangi beban drainase yang terjadi di permukaan.

g) Workability

Workability adalah kemudahan suatu campuran untuk dihampar dan dipadatkan sehingga memenuhi hasil yang diharapkan.Faktor yang mempengaruhi kemudahan dalam pelaksanaan adalah gradasi agregat, temperature campuran dan kandungan bahan pengisi.

\section{Metode Penelitian}

Penelitian ini menggunakan metode eksperimen, yaitu metode yang dilakukan dengan mengadakan kegiatan percobaan untuk mendapatkan data.Data yang diperoleh tersebut diolah 
dan dianalisis sesuai dengan syaratsyarat yang ada. Metode analisis yang digunakan dalam penelitian ini adalah deskriptif analitis, yaitu dengan mengindentifikasi permasalahan berdasarkan fakta dan data yang ada, serta menganalisis permasalahan berdasarkan pustaka dan data pendukung lainnya.

Penelitian dilakukan di Laboratorium Dinas Pekerjaan Umum Provinsi Riau Bidang Unit Pelaksana Teknis (UPT) Pengujian yang beralamat di Jalan Sudirman No.197 Pekanbaru. Dengan dasar menggunakan sistem pencampuran aspal panas $A C-B C$ dengan panduan Spesifikasi Umum Bina Marga 2010 yang merupakan dasar dari pembangunan jalan raya. Sedangkan standar-standar pengujian yang digunakan sebagian menggunakan standardari metode-metode yang disahkan atau distandarkan oleh Bina Marga bahkan ada yang telah menjadi Standar Nasional Indonesia (SNI).

Pengujian dalam penelitian ini dilakukan secara bertahap, yaitu terdiri atas pengujian agregat (kasar, halus dan filler), aspal dan pengujian terhadap campuran (uji Marshall). Pengujian terhadap agregat termasuk pemeriksaan berat jenis, pengujian abrasi dengan mesin Los Angeles, kelekatan terhadap aspal, indeks kepipihan dan penyerapan air. Untuk pengujian aspal termasuk juga pengujian penetrasi, titik nyalatitik bakar, titik lembek, kehilangan berat, daktilitas dan berat jenis. Sedangkan metode yang digunakan sebagai penguji campuran adalah metode Marshall, dimana dari pengujian Marshall tersebut didapatkan hasil-hasil yang berupa komponenkomponen Marshall, yaitu stabilitas, flow, void in the mineral aggregate (VMA), void in the compacted mixture (VIM), void filled with asphalt (VFA), dan kemudian dapat dihitung Marshall Quotient-nya sehingga didapat kadar optimum dari penggunaan abu tandan sawit dengan debu batu dan kadar optimum aspal.. Pengujian terakhir adalah berupa Pengujian Tingkat keausan (Cantabro Test).

Pengujian keausan perkerasan aspal (Cantabro Test) merupakan pengujian yang dimaksudkan untuk menentukan ketahanan lapis perkerasan terhadap keausan dengan menggunakan mesin Los Angeles tanpa menggunakan bola-bola baja. Keausan ini dinyatakan dengan perbandingan antara berat bahan sampel setelah 300 putaran terhadap berat semula sebelum dimasukkan kedalam mesin Los Angeles. Kehilangan berat ini dinyatakan dalam persen dengan perhitungan sebagai berikut:

Nilai keausan $=\frac{a-b}{b} \quad$ x $100 \%$ keterangan :

$$
\begin{aligned}
& \mathrm{a}=\text { Berat benda uji semula (gr) } \\
& \mathrm{b}=\text { Berat benda uji setelah } 300 \\
& \text { putaran }
\end{aligned}
$$




\section{Hasil dan Pembahasan}

Sebelum digunakan untuk material penyusun campuran, bahanbahan yang akan digunakan harus diuji karakteristiknya terlebih dahulu. Pengujian terhadap karakteristik bahan ini bertujuan untuk melihat apakah bahan tersebut layak untuk digunakan sebagai material penyusun campuran sesuai dengan standar yang berlaku. Adapun hasil yang didapat adalah sebagai berikut:

\section{a)Hasil Pengujian Agregat}

Agregat kasar yang digunakan dalam penelitian berasal dari Bangkinang. Hasil-hasil pengujian fisik terhadap agregat dapat ditampilkan pada Tabel 2 berikut.

Tabel 2. Hasil Pengujian Agregat Kasar

\begin{tabular}{|c|c|c|c|}
\hline Pengujian & Standar & Nilai Acuan & $\begin{array}{l}\text { Nilai Hasil } \\
\text { Pengujian }\end{array}$ \\
\hline $\begin{array}{l}\text { Kekekalan bentuk agregat } \\
\text { terhadap lanutan natrium dan } \\
\text { magnesium sulfat }\end{array}$ & SNI 3407:2008 & Maks. $12 \%$ & 0.58 \\
\hline $\begin{array}{l}\text { Abrasi dengan mesin Los } \\
\text { Angeles }\end{array}$ & & Maks. $40 \%$ & 34.94 \\
\hline $\begin{array}{l}\text { Kelekatan agregat terhadap } \\
\text { aspal }\end{array}$ & $\begin{array}{|ll|}\text { SNI } & 03-2439- \\
1991 & \\
\end{array}$ & Min. $95 \%$ & 100 \\
\hline \multirow[b]{2}{*}{ Partikel Pipih dan Lonjong } & RSNI T-01-2005 & \multirow[b]{2}{*}{ Maks. $10 \%$} & \multirow[b]{2}{*}{8} \\
\hline & $\begin{array}{l}\text { Perbandingan 1: } \\
5\end{array}$ & & \\
\hline $\begin{array}{lll}\text { Material lolos } & \text { Ayakan } \\
\text { No. } 200 & & \\
\end{array}$ & $\begin{array}{|ll|}\text { SNI } & 03-4142- \\
1996 & \\
\end{array}$ & Maks. $1 \%$ & - \\
\hline Berat Jenis & \multirow{5}{*}{ SNI 1969-2008 } & & \\
\hline - Berat Jenis Bulk & & & 2.56 \\
\hline - Berat Jenis SSD & & & 2.58 \\
\hline - Berat Jenis Apparent & & & 2.61 \\
\hline -Penyerapan & & & $0.67 \%$ \\
\hline
\end{tabular}

Agregat halus yang digunakan dalam penelitian ini berasal dari Bangkinang. Hasil-hasil pengujian fisik terhadap agregat dapat ditampilkan pada Tabel 3 berikut.
Tabel 3. Hasil Pengujian Agregat Halus

\begin{tabular}{|c|c|c|}
\hline Pengujian & Standar & $\begin{array}{l}\text { Nilai Hasil } \\
\text { Pengujjan }\end{array}$ \\
\hline Berat Jenis & \multirow{5}{*}{ SNI 1970-2008 } & \\
\hline - Berat Jenis Bulk & & 2.5 \\
\hline - Berat Jenis SSD & & 2.55 \\
\hline - Berat Jenis Apparent & & 2.62 \\
\hline - Penyerapan & & $1.81 \%$ \\
\hline
\end{tabular}

b) Hasil Pengujian Aspal Penetrasi $60 / 70$

Dalam penelitian ini Aspal Pen 60/70 yang digunakan diperoleh dari Laboratorium UPT Dinas Pekerjaan Umum. Pengujian terhadap aspal dilakukan sesuai dengan standar Spesifikasi Umum Bina Marga 2010. Hasil pengujian terhadap aspal tersebut dapat dilihat pada Tabel 4 berikut :

Tabel 4. Hasil Pengujian Aspal Penetrasi 60/70

\begin{tabular}{|c|l|c|c|c|}
\hline No. & \multicolumn{1}{|c|}{ Jenis Pengujian } & \multicolumn{1}{|c|}{ Standar } & $\begin{array}{c}\text { Nilai } \\
\text { Acuan }\end{array}$ & $\begin{array}{c}\text { Hasil } \\
\text { pengujian }\end{array}$ \\
\hline 1 & Penetrasi pada $25^{\circ} \mathrm{C}(\mathrm{dmm})$ & SNI 06-2456-1991 & $60-70$ & 64 \\
\hline 2 & Titik Lembek $\left({ }^{\circ} \mathrm{C}\right)$ & SNI 06-2434-1991 & $\geq 48$ & 53.15 \\
\hline 3 & Duktilitas pada $25^{\circ} \mathrm{C}$, (cm) & SNI-06-2432-1991 & $\geq 100$ & 127.5 \\
\hline 4 & Titik Nyala $\left({ }^{\circ} \mathrm{C}\right)$ & SNI-06-2433-1991 & $\geq 232$ & $>268$ \\
\hline 5 & Berat Jenis & SNI-06-2441-1991 & $\geq 1,0$ & 1.016 \\
\hline & Pengujian Residu hasil TFOT : & \multicolumn{3}{|l}{} \\
\hline 6 & Berat yang Hilang $(\%)$ & SNI 06-2441-1991 & $\leq 0.8$ & 0.00377 \\
\hline 7 & Penetrasi pada $25^{\circ} \mathrm{C}(\%)$ & SNI 06-2456-1991 & $\geq 54$ & 60.3 \\
\hline 8 & Duktilitas pada $25^{\circ} \mathrm{C}(\mathrm{cm})$ & SNI 062432-1991 & $\geq 100$ & 112.5 \\
\hline
\end{tabular}

Pengujian yang dilakukan terhadap aspal penetrasi 60/70 menghasilkan berat jenis aspal sebesar 1,016 dan memenuhi persyaratan Bina 
Marga yaitu minimal 1. Pada pengujian penetrasi aspal menghasilkan nilai penetrasi sebesar 64 dan penetrasi aspal setelah kehilangan berat adalah 60,3. Aspal yang telah diuji ternyata memenuhi persyaratan penetrasi aspal untuk penetrasi 60/70 yang minimal 60 dan maksimal 79 sedangkan penetrasi setelah kehilangan berat adalah minimal $75 \%$ dari penetrasi awal. Pada pengujian daktilitas menghasilkan daktilitas aspal 127,5 $\mathrm{cm}$ dan daktilitas setelah kehilangan berat sebesar 112,5 $\mathrm{cm}$. Pengujian daktilitas tersebut telah memenuhi persyaratan Bina Marga yaitu $100 \mathrm{~cm}$ dan daktilitas setelah kehilangan berat minimal $54 \mathrm{~cm}$.

Agar pencampuran dan pemadatan dapat menghasilkan campuran yang baik, maka salah satu syaratnya adalah kekentalan aspal harus cukup sedemikian sehingga peran aspal dalam proses pencampuran dan pemadatan dapat maksimal. Dalam penelitian ini menggunakan suhu pencampuran sebesar $155^{\circ} \mathrm{C}$ dan suhu pemadatan sebesar $145^{\circ} \mathrm{C}$.

Dilihat secara umum aspal yang digunakan pada penelitian ini telah memenuhi persyaratan spesifikasi sebagai aspal yang baik untuk digunakan sebagai bahan pengikat dalam campuran seperti yang ditentukan oleh Spesifikasi Umum Bina Marga.

\section{Kadar Optimum Penggunaan Abu Tandan Sawit}

Metode yang digunakan dalam menentukan kadar optimum adalah menggunakan metode pita berdasarkan RSNI M-01-2003 dengan menggunakan lima karakteristik Marshall yaitu menjabarkan grafik hasil stabilitas, kelelehan (flow), VIM, VMA dan $M Q$.

Setiap komposisi campuran dihitung nilai stabilitas, kelelehan (Flow), VIM, $V M A$ dan $M Q$. Nilai-nilai tersebut diuraikan pada grafik pada lampiran dengan dibatasi oleh standar Bina Marga. Garis yang berada dalam batasan Bina Marga lalu dipindahkan kedalam tabel kinerja Marshall. Kadar aspal optimum diperoleh dari nilai yang memenuhi semua kriteria Marshall tersebut. Adapun hasil dari penentuan Kadar Aspal Optimum yang didapat sebagai berikut:

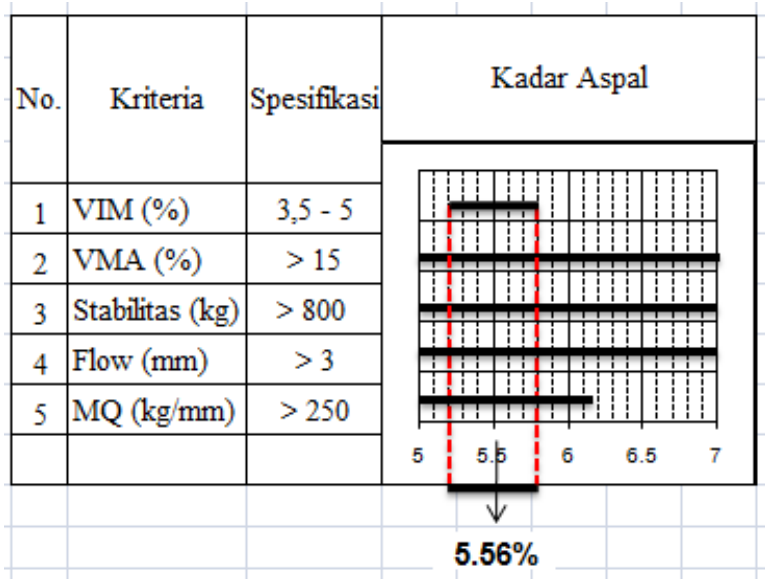

Gambar 1. Grafik KAO

\section{Cantabro Test}

Nilai

Cantabro

Test menggambarkan ketahanan benda uji terhadap keausan dengan menggunakan mesin Los Angeles. Dalam pengujian ini benda uji dalam kondisi Kadar Aspal Optimum sebesar 5,6\% dengan komposisi filler $75 \%$ abu batu $+25 \%$ abu 
tandan sawit dimasukkan kedalam mesin Los Angeles. Sebelum dimasukkan kedalam mesin Los Angeles di timbang berat awal setelah itu benda uji dimasukkan kedalam mesin Los Angeles. Cantabro test ini memberikan gambaran sejauh mana ketahanan perkerasan aspal terhadap menahan gesekan antara roda kendaran dengan permukaan jalan. Hasil perhitungan nilai Cantabro Test untuk semua variasi campuran dapat dilihat pada Tabel 5 berikut ini.

Tabel 5. Hasil pengujian Cantabro Test

\begin{tabular}{|c|c|c|c|}
\hline Variasi & $\begin{array}{c}\text { Berat } \\
\text { Awal }\end{array}$ & $\begin{array}{c}\text { Berat } \\
\text { Akhir }\end{array}$ & $\begin{array}{c}\text { Kehilangan } \\
\text { Berat (\%) }\end{array}$ \\
\hline Persyaratan & & & $\leq 20 \%$ \\
\hline $\begin{array}{c}75 \% \text { abu } \\
\text { batu+25\% abu } \\
\text { tandan sawit }\end{array}$ & 1175,57 & 1078,67 & 8,24 \\
\hline
\end{tabular}

Dari Tabel 5 diatas berdasarkan pengujian Cantabro Test didapat persentase kehilangan berat yaitu sebesar 8,24 \% dan dalam spesifikasi Bina Marga 2010 syarat kehilangan berat $\leq 20 \%$, sehingga dapat dianalisis pada komposisi optimum $75 \%$ abu batu+25\% abu tandan sawit sebagai filler pada campuran Asphalt ConcreteBinder Course (AC-BC) tahan terhadap keausan.

\section{KESIMPULAN DAN SARAN}

Kesimpulan

Dari penelitian karakteristik Marshall campuran beraspal dengan filler abu tandan sawit dapat diambil kesimpulan sebagai berikut :

1. Dari hasil penelitian dapat direkomendasikan campuran $A C$ $B C$ yang memenuhi Spesifikasi Umum Bina Marga 2010 25\% filler abu tandan sawit dicampur dengan 75\% Abu Batu dari berat total filler dalam campuran. Dari hasil tersebut didapat nilai Kadar Aspal Optimum sebesar 5,6\%.

2. Dari hasil pengujian Cantabro Test didapat persentase nilai kehilangan berat sebesar 8,24\% dimana spesifikasi Bina Marga 2010 syarat kehilangan berat $\leq 20 \%$ sehingga memenuhi persyaratan Bina Marga 2010

3. Dari nilai hasil kehilangan berat tersebut dapat dianalisis bahwasanya semakin banyak persentase abu tandan sawit maka nilai kehilangan berat semakin besar ini karena abu tandan sawit merupakan unsure organik.

Saran

1. Dapat dilakukan penelitian lebih lanjut mengenai pengaruh variasi filler pencampuran dan penumbukan terhadap filler lain.

2. Dapat dilakukan penelitian lebih lanjut mengenai pengujian unsur kimia dalam abu tandan kelapa sawit 


\section{UCAPAN TERIMA KASIH}

Ucapan terima kasih diberikan kepada semua pihak yang membantu dalam pelaksanaan penelitian ini kepada:

1. Lembaga Penelitian dan Pengabdian Masyarakat Universitas Lancang Kuning

2. Dekan fakultas Teknik Universitas Lancang Kuning

3. Laboratorium Jalan Raya dan Bahan Universitas Lancang Kuning dan PT.RMB

4. Laboratorium UPT Dinas Pekerjaan Umum.

5. Dan semua pihak yang tidak dapat disebutkan satu per satu yang sudah membantu dalam peelitian ini

\section{DAFTAR PUSTAKA}

Atkins, H. N. 1997. Highway materials, Soil, and Concretes. New Jersey: Prentice Hall.

Bina Marga. 1990. SK SNI M 58-199003, Metode Pengujian Campuran Aspal dengan Alat Marshall. Jakarta: Dep PU.

Bina Marga. 2010. Spesifikasi Umum Divisi 6 Perkerasan Aspal. Jakarta: Dep PU.
Hatherly, L. W. Leaver, P.C. 1967. Asphaltic Road Materials. London: Edward Arnold Ltd.

Kerbs, R.D. and Walker, R.D. 1971. Highway Materials, McGraw Hill, New York.

Mutohar, Y. 2002. Evaluasi pengaruh Bahan Filler Fly Ash Terhadap Karakteristik Campuran Emulsi Bergradasi Rapat (CEBR). Tesis Magister, Universitas Diponegoro Semarang, Semarang.

Pembuatan dan Karakterisasi Batako menggunakan Abu. Available at : $<$ URL

http://repository.usu.ac.id/bitstrea $\underline{\mathrm{m} / 123456789 / 16586 / 4 / \text { Chapter\% }}$ 20II.pdf> [Accessed 15 Oktober 2011].

RSNI M-01-2003, Metode pengujian Campuran Beraspal Panas Dengan Alat Marshall.

Shell Bitumen. 1990. The Shell Bitumen Hand Book, Shell Bitumen UK, UK.

SNI-03-6723-2002, Spesifikasi Bahan Pengisi Untuk Campuran Beraspal.

Sukirman, S, (2003), Beton Aspal Campuran Panas, Nova, Bandung. 